\title{
Combination of Introduction and Cultivation, Establish an Independent College Information Specialty Teachers' Team with Reasonable Structure and Excellent Teaching Style
}

\author{
$\operatorname{Lin} \operatorname{Bin}^{1, a, *}$ \\ ${ }^{1}$ Xiamen University Tan Kah Kee College, Fujian Zhangzhou 363105, China \\ alinbin@xujc.com \\ ${ }^{*}$ Lin Bin
}

Keywords: The introduction of teachers, The cultivation of teachers, Independent college information specialty, Teachers' team.

\begin{abstract}
Teachers are the most valuable asset of the university, the quality of teachers directly determines the level of teaching and scientific research, directly affects the quality of personnel training. Independent college information specialty should combination of introduction and cultivation, efforts to build a teachers' team that have the high level of research, advanced teaching methods and effective guidance method. This paper introduces the construction goal and the construction methods of independent college information specialty teachers' team, summarizes the experience of the introduction and cultivation of teachers.
\end{abstract}

\section{Introduction}

As the core of teaching, teachers' team plays a decisive role in the quality of teaching. The information specialty is the specialty which pays great attention to the practice, the information specialized teacher needs not only has the solid theoretical knowledge, but also has the rich engineering practice experience. Independent college information specialty should introduce a number of academic leaders with senior professional title, rich academic experience and project experience; accelerate the pace of discipline construction. Through the recruitment, introduce of a number of high-level teaching and technical personnel as a full-time teacher, through a few years of training and teaching practice, let them to become the main force of teaching and research. Pay attention to introduce double-professionally-titled, highly educated, high professional title and high level talents to enrich the teachers' team, encourage teachers to introduce scientific research results into teaching [1-2].

Independent college information specialty should strengthening the cultivation of young teachers, assign experienced teachers to give guidance to young teachers, help young teachers to establish a good concept of teachers' ethics, discuss teaching methods, improve the teaching skills and teaching level of young teachers, help young teachers to grow rapidly.

\section{The construction goal of independent college information specialty teachers' team}

Combination of introduction and cultivation, establish an independent college information specialty teachers' team with reasonable structure and excellent teaching style, efforts to build a teachers' team that have the high level of research, advanced teaching methods and effective guidance method. On the basis of the existing teachers, continue to increase the introduction of talent, and constantly improve the overall strength of the teaching team. Strengthen the training of teaching staff, and assign experienced teachers to guide young teachers to improve their teaching skills and teaching level. Vigorously carry out teaching reform and innovation, promote the combination of effective teaching, scientific research education, creative education, and practical education, and promote the further enhancement of teaching effect. 
The teachers that have the high level of research grasp the latest research direction and the most advanced research methods, can continue to introduce the latest scientific research results into teaching, can provide technical support for students' innovation ability training. The teachers that have the advanced teaching methods master the law of teaching, and can help students to improve their practical ability and innovation consciousness through the course study and practice training. The teachers that have the effective guidance method can lead students to actively participate in scientific and technological innovation activities, maximize the ability of students to stimulate innovation, and gradually guide students to embark on the academic road. The teachers that have the high level of research, advanced teaching methods and effective guidance method not only impart knowledge and cultivate ability, they are also the students' growth guiders [3-4].

\section{The construction methods of independent college information specialty teachers' team}

\subsection{Perfect the teachers' introduction plan}

Independent college information specialty should full use of the advantages of the parent school teachers, employing a number of well-known professors, as part-time teachers, carry out discipline construction, and promote young teachers to learn and progress.

Independent college information specialty should hired a group of experienced enterprises engineers as part-time teachers, not only played a very good practice demonstration effect, but also provides the company's demand information, make the practice training more appropriate to the needs of enterprises.

Independent college information specialty should through the recruitment, introduce of a number of high-level teaching and technical personnel as a full-time teacher, through a few years of training and teaching practice, let them to become the main force of teaching and research.

\subsection{Strengthen the training of double-professionally-titled teachers}

Independent college information specialty should through the establishment of a reasonable policy, in the distribution of income and title promotion, all give priority to ascend, encourage and support young teachers to become double-professionally-titled teachers. Let more teachers can not only talk about the theory class in the classroom, but also can demonstrate in the laboratory, guide the students to experiment, strengthen the relationship between theory and practice, ensure that teachers can do combining theory with practice in the teaching.

Independent college information specialty should Support for the research work of young and middle-aged teachers and the promotion of scientific research achievements, provide matching funding support for young and middle-aged teachers' scientific research projects and teaching reform projects, allow more teachers to strengthen practical ability through scientific research training. Develop the lifelong training plan for excellent teachers; comprehensive train of teachers in the aspects of theoretical teaching, practical teaching, scientific research and practical project development, improve the teaching ability of the teachers through the study of many kinds of ways, such as further education and on-the-job graduate students.

Independent college information specialty should bring in enterprise elements in teacher training system. Through the school enterprise cooperation, encourage young teachers to use the winter vacation and summer vacation to the enterprise to receive training, to understand the latest industry trends, participate in the actual project development. Further enrich the young teachers' professional knowledge and engineering experience, improve the practical ability of young teachers.

\subsection{Optimizing the management system of teachers}

Independent college information specialty should optimize the method of teacher evaluation, comprehensive evaluate teachers' workload and quality of each task, quantitative teaching, scientific 
research, discipline construction management and other work, bring the assessment results of the each work into the annual performance appraisal. Let Independent college information specialty become the academic community of teachers. Let every teacher is willing to contribute to the development of this academic community to contribute their wisdom and strength. Insisting on the teacher as the center in the discipline construction, Academic director and administrative staff should adhere to the service for teachers and teaching. In the training study, salary welfare, and housing allocation, should priority ensure take care the teachers that work in the first line.

Independent college information specialty should give full play to teachers' management ability and the sense of being master, through the establishment of a reasonable computing method of the teachers' workload, effectively attract high-level teachers to participate in scientific research and discipline construction management activities, form the core team of teaching and scientific research with high academic level, enhance the innovation ability of teachers' team, improve the comprehensive execute ability of teachers' team.

\subsection{Strengthen cooperation between independent college information specialty and enterprises, enhance the ability to serve the community}

Independent college information specialty should cooperate with enterprises to build scientific research platform, enterprises provide research funding and research equipment, independent college provides research sites and matching funds, organize independent college information specialty teachers and students, cooperate with the project engineer of enterprises, carry out the scientific research work in view of the enterprise technical problems needed to resolve. In the process of cooperation, enterprises can get strong intellectual support; independent college information specialty teachers and students can training scientific research ability, obtain the scientific research achievement with the application prospect, and write scientific research paper. This is a win-win model for both enterprises and independent college information specialty teachers and students.

Independent college information specialty should further strengthen communication with local enterprises and local government departments, and build a platform for teachers serve local economic construction, encourage teachers through the transverse joint way, participate in the applied research and the applied basic research project of local enterprises and local government departments. Independent college information specialty should give full play to the advantages of flexible mechanism of private universities, when calculating the workload of scientific research, should fully consider the teachers' work that participation in the service for local enterprises and local government departments. Through the depth of cooperation with enterprises and local government departments, the independent college, enterprise and government combined to carry out practical research and development work, promote the development of local economy, and finally the research results will be feedback to teaching.

Independent college information specialty should increase the investment in the construction of laboratory infrastructure and the renewal of experimental equipment, ensure the laboratory scale and the level of laboratory equipment can meet the needs of teaching and research work. While doing a good job in the construction and maintenance of existing laboratories, independent college information specialty should strengthen the construction of joint laboratory with famous enterprises; make full use of enterprises' funds and equipment to build a number of high-level laboratories. In the process of building the joint laboratory, independent college information specialty should have a certain forward-looking, the instrument and equipment of the joint laboratory should not only meet the needs of teaching and practice, but also be able to meet the needs of scientific research work. Independent college information specialty should formulate long-term development plan for each joint laboratory, let each joint laboratory become a joint scientific research platform in a planned way. Through the construction of the joint laboratory, can not only introduce the latest equipment of the enterprise, complete laboratory equipment upgrading, but also through the enterprise training complete full-time teachers' enhance of the engineering knowledge. 


\section{A new model of innovative practice teaching of independent college information specialty}

The success of the cultivation of practical ability and innovation ability is directly related to the quality of the cultivation of information specialty innovative talents. Independent college information specialty should organize teachers to use their spare time, through lectures, training, centralized guidance and other forms, help students understand the characteristics of the scientific research of the specialty, develop their own scientific research plan, familiar with the application of equipment, experimental methods, data analysis, thesis writing, patent applications and other research processes, and consciously abide by the scientific research ethics and scientific research standards. The teachers lead students to participate in scientific research and innovation activities, cultivate students' interest in learning, active academic atmosphere, and establish a good interactive mechanism between teachers and students, build a science technology innovation team composed of teachers and outstanding undergraduate students [5-6].

\section{Conclusions}

In the process of teaching team construction, independent college information specialty should focus on improving students' practical ability and innovation ability, adhere to policy oriented, strictly implement recruitment standards, continuously improve the teachers' level of teaching and scientific research, strive to make the teaching team to meet the requirements of teaching reform. Independent college information specialty should through policy guidance, stable full-time teachers, pay attention to the use of high level part-time professors and part-time enterprises engineer, let they can play a greater role in discipline construction and teaching reform. Independent college information specialty should introduce a large number of double-professionally-titled talents to enrich the teaching team, ensure that they can teach theory courses, and guide students to practice. Independent college information specialty should establish a new mode of innovative practice teaching, strengthen the impetus of scientific research to teaching, strengthen the ability of serve the enterprises and society, ensure the independent college's teaching, scientific research, graduate design, and innovation projects can meet the needs of society. Adhere to the combination of introduction and training, independent college information specialty can build a teachers' team that have the high level of research, advanced teaching methods and effective guidance method.

\section{References}

[1] N. Liu, J. H. Zhao, Exploration on construction of "double qualification" teaching staff under the background of transformation and development, Microcomputer Applications, vol.32, pp. 35-37, 2016.

[2] M. H. Li, R. R. Gu, Research on the way of the constructions of "double-qualified teachers" in local application-oriented universities, Journal of Jinling Institute of Technology(Social Science), vol.28, pp. 75-78, 2014.

[3] G. J. Peng, H. G. Zhang, R. Y. Du, Information security competition and exploration of the innovative and practical ability of undergraduate, Computer Education, vol.8, pp. 1-4, 2010.

[4] H. R. Wang, L. Sun, X. J. Wang, Curriculum system settings of innovation oriented talents cultivation based on "subject competition", The World and Chongqing, vol.7, pp. 117-121, 2016.

[5] S. P. Zhong, B. Liao, The role of university research team "heirloom" in the cultivate of information specialty undergraduates, Heilongjiang Education, vol.67, pp. 63-65, 2013.

[6] S. F. Hao, Improvement of occupational literacy of undergraduates majoring in medical informatics by establishing a model of "cooperative scientific research team of teachers and students", Chinese Journal of Medical Library and Information Science, vol.21, pp. 37-39, 2012. 